\section{Cutaneous melanoma in Latin America: a population-based descriptive study}

\author{
Melanoma cutâneo na América Latina: \\ estudo descritivo de base populacional
}

\author{
${ }^{1}$ Hospital 9 de Julho, São \\ Paulo, Brasil. \\ 2 Cancer Information Center, \\ International Agency for \\ Research on Cancer, Lyon, \\ France. \\ Correspondence \\ M. P. Curado \\ Cancer Information Center \\ International Agency for \\ Research on Cancer. \\ 15, Chemin Du Saquin, \\ Espace Européen, 69130, \\ Ecculy, France. \\ maria-paula.curado@i-pri.org
}

\section{Abstract}

Cutaneous melanoma incidences vary between geographic regions and are a health concern for Caucasians and for all ethnic populations. In Latin America, data from population-based cancer registries of cutaneous melanoma incidence rates have rarely been reported. We searched the Cancer Incidence in Five Continents volume IX (CI5-IX) database for cutaneous melanoma and select cases by topography (C43) from 11 population-based cancer registries in Latin America. Between 1998 and 2002, a total of 4,465 cutaneous melanoma cases were reported in Latin America. The average age-standardized incidence rates (per 100,000 persons-year) was 4.6 (male) and 4.3 (female). This study presents an overview of cutaneous melanoma incidence in Latin America, highlighting the need to enhance coverage of populationbased cancer registries in Latin America, to allow for a better understanding of this neoplasm in the region. Thus it can help in implementing primary prevention programs for the whole Latino population. At this point in time, early detection messages should target young women and older men in Latin America.

Melanoma; Neoplasms; Incidence
Ana Maria Sortino-Rachou 1

Maria Paula Curado 2

Marianna de Camargo Cancela ${ }^{2}$

\section{Introduction}

Cutaneous melanoma incidence rates vary considerably between geographic regions and represent a public health concern for all ethnic populations 1. In a global scale, melanoma of skin is estimated to be the $12^{\text {th }}$ and $15^{\text {th }}$ most commonly diagnosed cancer, with 3.1 and 2.6 age-standardized incidence rates (ASRW) per 100,000 persons-year, in males and females respectively 2 . Nevertheless, in some developed countries it is the first or second tumor in young adults 3 . High melanoma occurrence is observed in Australia and regions where the Caucasian population is predominant. Intermediate and low incidence rates are seen in Latin America, however the lowest rates are in areas of mainly Asian or African inhabitants 4.

It has been postulated that skin melanoma is a good example of a disease for which an agespecific incidence pattern can be explained by an environmental stress being suddenly and permanently imposed on a whole population 5 . Both familial and environmental factors play a role in the etiology of melanoma ${ }^{4}$. Sun exposure, dysplastic nevi and fair skin are risk factors extensively discussed in the literature 6,7. More recently, studies have presupposed that DNA repair capacity may modify the risk of melanoma in the presence of other strong risk factors 5,8. A reduced efficiency of the cell-repairing mechanisms is capable of explaining the increasing trends of melanoma in- 
cidence that has been noticed since the mid-20th Century ${ }^{9}$. Additionally, melanoma can occur in any ethnic group and in people who have not had substantial sun exposure 10 .

In Latin America, most epidemiological studies describe cases from a single institution 11,12 and rates on melanoma incidence have rarely been reported 13 . Our main goal was to verify the incidence rates for cutaneous melanoma in Latin America by gender and age-group for the period of 1998 to 2002, using the Cancer Incidence in Five Continents volume IX (CI5-IX), a secondary database where patients are not identified ${ }^{3}$.

\section{Patients and methods}

Incidence data are based on primary malignant tumors diagnosed among the population covered by eleven cancer registries in Latin America and then submitted to the CI5-IX, for the period of 1998 to 2002. All population-based cancer registries submitted the following variables: case registration number, gender, age-group, date of incidence, most valid basis of diagnosis, tumor topography, morphology and behavior. The data was aggregated by 5 -year periods. All cases were coded using the International Classification of Diseases for Oncology (ICDO3) 14. Primary invasive melanoma of skin were retrieved from the database with topography codes C43.0-lip, C43.1-eyelid, C43.2-ear, C43.3-unspecified parts of face, C43.4-scalp and neck, C43.5-trunk, C43.6upper limb, C43.7-lower limb, C43.8-overlapping and C43.9-melanoma - not otherwise specified (NOS). To allow comparison within different regions the direct method of standardization by the world standard populations of Segi was used. The age-standardized incidence rates are calculated first by estimating the age-specific rates and then applying these rates to the reference population of each registry area 15.

Data were organized by gender, age-groups (from 0 to 70 and older, in 5-year periods) and topography (head and neck, trunk, upper limb, lower limb and NOS). Skin melanoma age-standardized incidence rates were calculated for the period 1998-2002. In the database 321 men and 443 women were reported as age unknown and 20 cutaneous melanoma cases were registered in the younger age groups (seven cases in the 0-4 age-group and 13 cases in the 10-14 age-group), therefore they were excluded from graphical analysis. Male to female incidence rate ratios were calculated for each Latin America population-based cancer registry 16. For data tabulation and figures Excel for windows (version 10.0; Microsoft Corp., USA) was used.
The relatively high incidence in the city of São Paulo, Brazil, lead us to search the CI5-IX website for graphical comparisons of cutaneous melanoma between this big urban cluster and: (1) a region of similar latitude, due to a possible link between risk of cutaneous melanoma and latitude 17; (2) regions with Hispanic and NonHispanic white population based on similar incidence in the USA, Surveillance Epidemiology and End Results (SEER) for the period studied 18.

\section{Results}

Population-based cancer registries in the region have a coverage of 22.7 million inhabitants, representing approximately $4.3 \%$ of the Latin America population. Between 1998 and 2002, a total of 4,465 cases of melanoma were reported to the CI5-IX database by eleven cancer registries in Latin America. This geographic region represents $1.2 \%$ of all cutaneous melanoma registrations in the CI5-IX database $(n=382,371$ cases). In Latin America, incidence rates for melanoma varied widely from 1.1 to 6.5 (ASRW) per 100,000 persons-year within both sexes for all ages and regions. Based on our dataset, the average incidence rates were 4.6 and 4.3 (ASRW) per 100,000 persons-year for women and men, respectively.

The gender distribution of cutaneous melanoma cases was: 2,041 (46\%) men and 2,424 (54\%) women. The male:female ASRW incidence ratios were highest for Cuiabá, Brazil (1.4) and lowest for Valdivia, Chile (0.5). The number of melanoma cases and ASRW incidence rates for all ages according to gender and geographic region are shown in Table 1 . The mean age of cutaneous melanoma diagnosis for both sexes and all registries in Latin America falls into the 60 to 64 age-group. In the younger, 25-49 age groups the ASRW is higher for females than for males. Conversely, in the older age-groups (60 or more), the ASRW for males is higher than for females (Figure 1). In regard to data quality and morphology, microscopic verification was available for $97.2 \%$ of all registered skin cancers (melanoma and nonmelanoma) cases.

In Latin America the incidence of melanoma is slightly higher in males than in females (male: female ratio of 1.1). For all ages, the highest ASRW (per 100,000 person-years) were observed among men (6.5) and women (5.7) in São Paulo, Brazil and the lowest were found for men (1.4) and women (1.1) in La Martinique, France. The age-specific incidence pattern shows remarkably higher rates among the elderly, especially men 70 years or older with an ASRW of 36.5 (Figure 1). 
Age-standardized incidence rates of skin melanoma per 100,000 people by gender and population-based cancer registries for all ages.

\begin{tabular}{|c|c|c|c|c|c|c|c|c|}
\hline \multirow[t]{2}{*}{ Regions } & \multicolumn{3}{|c|}{ Male } & \multicolumn{3}{|c|}{ Female } & \multirow{2}{*}{$\begin{array}{l}\text { Ratio } \\
M / F\end{array}$} & \multirow{2}{*}{$\begin{array}{c}\text { Mean } \\
\text { age-group }\end{array}$} \\
\hline & Cases & ASRW & $95 \% \mathrm{Cl}$ & Cases & ASRW & $95 \% \mathrm{Cl}$ & & \\
\hline Argentina, Bahia Blanca & 27 & 3.3 & $2.0-4.6$ & 29 & 2.9 & $1.8-4.1$ & 1.1 & $55-59$ \\
\hline Brazil, Goiânia & 69 & 4.4 & $3.3-5.5$ & 93 & 4.5 & $3.6-5.5$ & 1.0 & $50-54$ \\
\hline Brazil, São Paulo & 1,392 & 6.5 & $6.1-6.9$ & 1,687 & 5.7 & $5.4-6.0$ & 1.1 & $60-64$ \\
\hline Brazil, Brasília & 102 & 4.2 & $3.3-5.2$ & 122 & 4.3 & $3.4-5.1$ & 1.0 & $50-54$ \\
\hline Brazil, Cuiabá & 16 & 2.6 & $1.3-4.0$ & 15 & 1.9 & $0.9-3.0$ & 1.4 & $50-54$ \\
\hline Chile, Valdivia & 16 & 1.8 & $0.9-2.7$ & 32 & 3.5 & $2.3-4.7$ & 0.5 & $50-54$ \\
\hline Colombia, Cali & 124 & 3.5 & $2.8-4.1$ & 135 & 2.9 & 2.4-3.5 & 1.2 & $55-59$ \\
\hline Costa Rica & 188 & 2.4 & $2.0-2.8$ & 173 & 2.1 & $1.8-2.4$ & 1.1 & $55-59$ \\
\hline Equador, Quito & 73 & 2.5 & $1.9-3.1$ & 96 & 2.9 & 2.3-3.5 & 0.9 & $55-59$ \\
\hline France, La Martinique & 18 & 1.4 & $0.7-2.1$ & 19 & 1.1 & $0.6-1.6$ & 1.3 & $60-64$ \\
\hline Peru, Trujillo & 16 & 1.8 & $0.9-2.8$ & 23 & 2.1 & $1.2-2.9$ & 0.9 & $60-64$ \\
\hline Total & 2,041 & 4.6 & $4.3-4.7$ & 2,424 & 4.3 & $4.2-4.4$ & 1.1 & $60-64$ \\
\hline
\end{tabular}

ASRW: age-standardized incidence rate; $95 \% \mathrm{Cl}$ : 95\% confidence interval.

Source: Cancer Incidence in Five Continents volume IX (CI5-IX).

\section{Figure 1}

Skin melanoma ASRW by gender and age-group for Latin America (1998-2002).

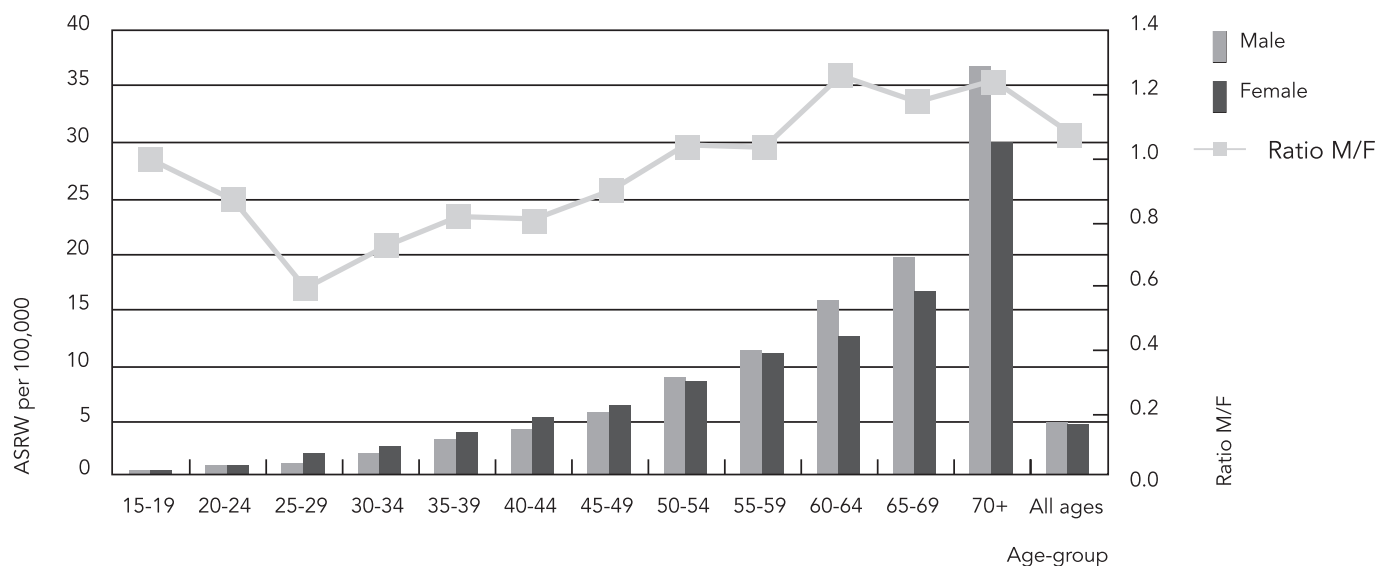

ASRW: age-standardized incidence rates.

In regard to topography and considering both genders an expressive number of cutaneous melanoma cases were of unknown sites and therefore classified as NOS and overlap ( $\mathrm{n}=1,344,30.1 \%$ ). However, the most frequent anatomical location for melanoma was the trunk ( $n=502,25 \%)$ and head and neck $(n=366,18 \%)$ for men and lower limbs $(\mathrm{n}=681,28 \%)$ and trunk $(\mathrm{n}=394,16 \%)$ for females (Figure 2).

The comparison between two regions of similar latitude as the city of São Paulo, Brazil $\left(23^{\circ} \mathrm{S}\right)$ and the Western region of Australia $\left(24^{\circ} \mathrm{S}\right)$ showed a wide variation of incidence rates (Figure 3). 


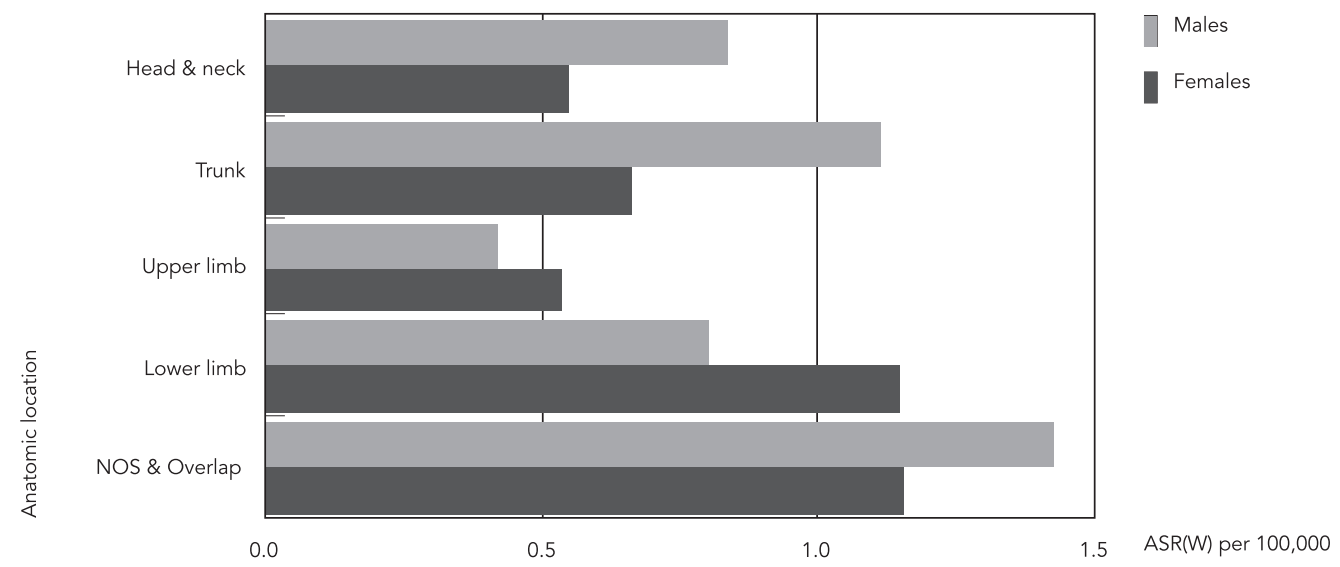

Figure 3

Skin melanoma in São Paulo, Brazil and the Western region of Australia by age-standardized incidence rates (ASRW) and gender (1998-2002).

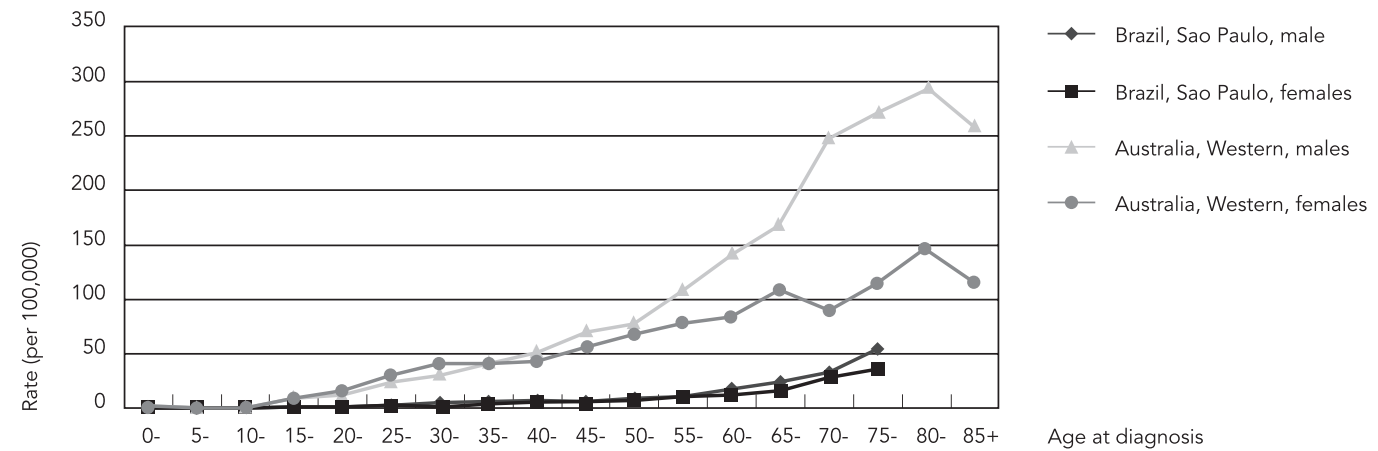

In Latin America there is no race/ethnicity distinction in the population-based cancer registries. Specific data by race is available in the USA (SEER) where Hispanic males and females had a melanoma rate of 3.0 and 3.2 per 100,000, respectively, between 1998 and 2002 3, surprisingly lower than the mean standardized cutaneous melanoma incidence rates for Latin America. When comparing Hispanic-whites from the city of Los Angeles, USA with the population of the city of São Paulo, we see higher incidence rates of cutaneous melanoma in São Paulo, for both gender, in individuals 45 and older (Figure 4).

\section{Discussion}

Cancers are complex diseases which show endogenous metabolic changes, imbalances associated to aging and genetic changes, partly caused by exogenous factors, such as lifestyle and exposure to ultraviolet radiation in the case 
Skin melanoma in São Paulo, Brazil and Los Angeles, USA (Hispanic White) by age-standardized incidence rates (ASRW) and gender (1998-2002).

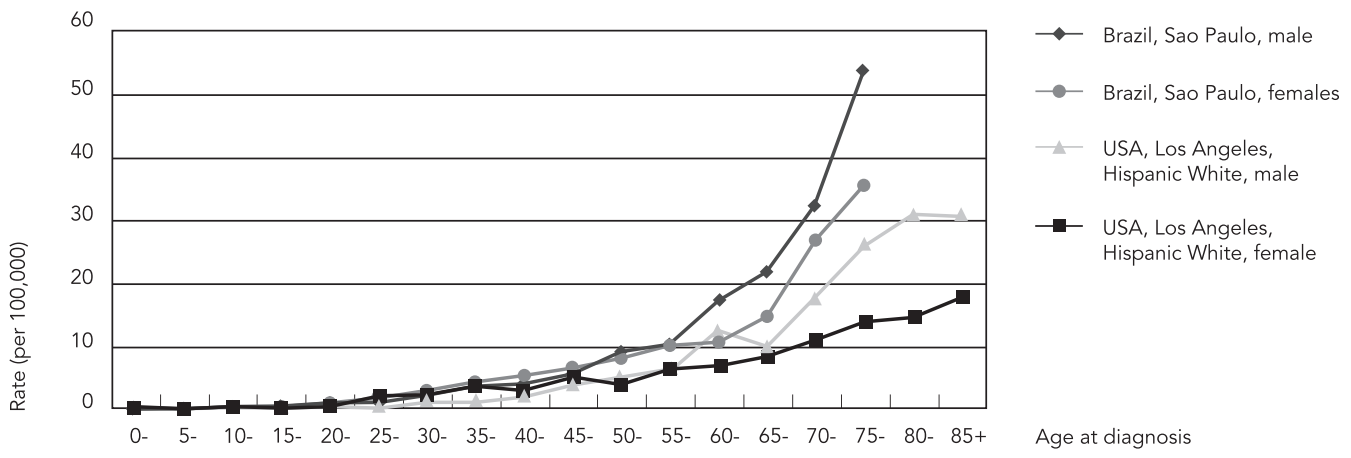

of melanomas 19,20,21. Cutaneous melanoma is the most lethal form of skin cancer, accounting for about $75 \%$ of all skin cancer deaths. Generally, incidence rates increase with age, peak after the age of 40 , and are greater in men than in women. However, these trends do not reflect what is typically seen in minority ethnic groups, where incidence rates are lower 22.

To take a deeper look on cutaneous melanoma in Latin America, we searched the CI5-IX database and found that cutaneous melanoma accounts for $1.5 \%$ of all cancers, comparable in magnitude to pancreatic and gallbladder cancer in women and to pancreatic and kidney cancer in men ${ }^{3}$. Invasive melanoma represented $7 \%$ of all skin cancer registrations in the region for the period, higher than the $4 \%$ widely expressed in literature 23 .

When compared to the most frequent solid tumors, melanoma is diagnosed at a relatively younger age 4,24 . We found, in younger age groups, a higher incidence of cutaneous melanoma among women, perhaps due to the low perception of sun exposure risks among adolescents and young adults, an excessive aesthetic need to have a tan (natural or artificial) in order to look good and a greater tolerance to sunburn 25,26 . Besides, outdoor sports are very common in warmer regions and sun protection has been shown to be insufficient with frequent sunburns 27. Conversely, a 50-year period population-based cancer registry study from Manitoba, Canada, showed decreasing incidence rates for young women 28 .
Middle-aged and older men are recognized as a high-risk group ${ }^{29}$, probably due to low prediagnosis awareness of melanoma warning signs and poor skin self-examination practices 30 . In Latin America there are also elevated incidence rates of invasive melanoma among males in older age-groups (60 or more), perhaps associated with age-associated changes in the immune system, lower socioeconomic groups and late diagnosis due to a relative lack of access to medical care $29,30,31$.

The literature points to a general melanoma pattern whereby, in relatively low-incidence countries, female incidence rates exceed those of males. On the other hand, in higher-incidence countries such as Australia and the United States, the incidence is either equal, or there is a male preponderance 32,33 . In Latin America we found a slight male preponderance, leading to the question: can some countries in the region be moving toward the pattern of an intermediate incidence country?

For the period under study, we found less striking mean standardized cutaneous melanoma incidence rates for Latin America (4.6 for male and 4.3 for female) when compared to developed regions of the world such as Europe (7.5 for male and for 8.3 female), North America (12.9 for male and 9.2 for female) and Oceania (36.4 for male and 28.1 for female) 3 . These continents show a continuing rise in incidence, although in some countries figures may be stabilizing or decreasing in younger females 28,34 . By looking at melanoma trends in different ethnic groups, recent studies have demonstrated that cutaneous melanoma 
is growing among Mediterraneans with a $6.4 \%$ mean annual increase in the risk of cutaneous melanoma diagnosis in central Italy 35 , while Hispanics showed a statistically significant $7.3 \%$ annual increase in the incidence of invasive melanoma among males in California, USA, between 1996 and 2001 36. One analysis from Goiânia, Brazil, between 1988 and 2000, showed an annual increase in incidence of $6.9 \%$ for men and $8.3 \%$ for women 13 . These are all higher than the rate in Queensland, Australia, which showed an annual increase of $2.6 \%$ for men and $1.2 \%$ for women between 1982-2002 32 and the overall 3.1\% annual statistically significant increase for white Americans between 1992-2004 32. Conversely, data analyzed by the Singapore Cancer registry, between 1968 and 2006, showed a constant cutaneous melanoma rate for three different low incidence races: Malays, Chinese and Indians 37.

Although age-adjusted incidence rates (per 100,000 ) for cutaneous melanoma are significantly lower among Hispanics (4.5) compared with non-Hispanic whites (21.6), cutaneous melanoma among minority populations are more likely to present at advanced stages and have poorer outcomes compared with Caucasians 38 . In addition, Hispanic males have an approximately $11 \%$ higher frequency of thick melanomas at diagnosis 36 , elevating health costs with a solid tumor that can usually be diagnosed and successfully treated at an early stage 39 . The large economic burden of melanoma in patients aged 65 and over is comparable to that of other common malignant neoplasms in this population 40 . It has been estimated that if all patients were diagnosed and effectively treated in cutaneous melanoma stage 0 or I, the annual direct costs for the over 65 population would be $40 \%$ to $65 \%$ of the current cost 40 .

The highest non-melanoma skin cancer incidence rates in the world are in Australia and Brazil 41. Our findings also show, that besides the important cutaneous melanoma incidence gap between these two southern countries (Figure 3), São Paulo, has the highest cutaneous mela- noma incidence rates within Latin America. There are several possible considerations for these findings: Brazil, especially São Paulo and the Southern States, have experienced centuries of immigration, mostly from European countries 42 , with unique racial miscegenation 13; the city is at an altitude of $790 \mathrm{~m}$ or $2,592 \mathrm{ft}$ and approximately 80 kilometers/50 miles from the coast, facilitating intermittent sun exposure habits (weekends, holidays and vacation) of its inhabitants 43,44,45; and it is a big urban cluster with an abundant concentration of high-rise buildings and radio frequency electromagnetic radiation that may have an effect on the immune defense system, cell repair and apoptosis mechanisms 45,46 .

Topographically, our findings are consistent with those in the literature where the trunk is the most common primary site for males and the lower limb for females 28,34. Cutaneous melanoma distribution over body surface area may be explained by the hypotheses that working indoors during the day (artificial barrier by window glass) divides UVB from UVA and may have inadvertently increased the incidence of melanomas. It is known that intermittent UVB intense exposure and sunburn promotes melanoma initiation and that UVA may act promoting mutations and tumor growth 45 .

Our analysis has identified low and intermediate incidence rates in Latin America that need to be investigated through in-depth studies in order to better elucidate regional trends and potential risk factors, since it appears to be increasing more rapidly than in developed countries. However, our data covers less than $5 \%$ of the population, making clear the importance of continuous efforts in improving cancer registration in low and medium income countries. We are in agreement that, if effective, prevention and early detection attempts may reduce the economic burden of melanoma 40 . Moreover, activities aimed at the early diagnosis of cutaneous melanoma must target young women 26 and older men in the region 40 . 


\section{Resumo}

A incidência de melanoma cutâneo varia entre regiões geográficas e é preocupante tanto para a população de pele clara como outras etnias. Na América Latina, dados de incidência de melanoma cutâneo oriundos de registros de câncer de base populacional são escassos. Uma busca na base de dados do Cancer Incidence in Five Continents, volume IX (CI5-IX), foi realizada para melanoma cutâneo pela topografia (C43), e casos de 11 registros de câncer de base populacional na América Latina foram selecionados. Entre 1998 e 2002, encontrou-se um total de 4.465 casos de melanoma cutâneo na América Latina. Os coeficientes padronizados médios de incidência (por 100 mil pessoas-ano) foram 4,6 (homens) e 4,3 (mulheres). Este estudo descreve o panorama da incidência de melanoma cutâneo na América Latina e pontua a necessidade de reforçar a cobertura dos registros de câncer de base populacional nos países sul-americanos, o que permitiria uma melhor compreensão dessa neoplasia, facilitando a implementação efetiva de programas de prevenção primária para toda a população latina. Neste momento, as mensagens de detecção precoce do melanoma cutâneo devem ter, como alvo, mulheres jovens e homens mais velhos na população da América Latina.

Melanoma; Neoplasias; Incidência

\section{Reference}

1. Cormier JN, Xing Y, Ding M, Lee JE, Mansfield PF, Gershenwald JE, et al. Ethnic differences among patients with cutaneous melanoma. Arch Intern Med 2006; 166:1907-14.

2. Ferlay J, Shin HR, Bray F, Forman D, Mathers C, Parkin DM. GLOBOCAN 2008, cancer incidence and mortality worldwide: IARC CancerBase No. 10. Lyon: International Agency for Research on Cancer; 2010. http://globocan.iarc.fr (accessed on 08/ Sep/2010).

3. Curado MP, Edwards B, Shin HR, Strom H, Ferlay $\mathrm{J}$, Heanue M, et al. Cancer incidence in five continents - volume IX. http://www-dep.iarc.fr (accessed on 17/Aug/2008)

4. de Vries E, Bray F, Coebergh JW, Cerroni L, Ruiter DJ, Elder DE, et al. Melanocytic tumours. In: LeBoit PE, Burg G, Weedon D, Sarasin A, editors. Skin tumours. Lyon: IARC Press; 2006. p. 49-120.

5. Hallberg O. Increasing incidence of malignant melanoma of skin can be modeled as a response to suddenly imposed environmental stress. Med Sci Monit 2005 10; 11:CR457-61.

6. MacKie RM. Risk factors for the development of primary cutaneous malignant melanoma. Dermatol Clin 2002; 20:597-600.

\section{Contributors}

A. M. Sortino-Rachou participated in the conception and design, acquisition of data, analysis and interpretation, and drafting the article. M. P. Curado participated in the conception and design, drafting and revising, and final approval. M. C. Cancela participated in the acquisition of data, analysis and interpretation, and revising.
7. Tucker MA, Fraser MC, Goldstein AM, Struewing JP, King MA, Crawford JT, et al. A natural history of melanomas and dysplastic nevi: an atlas of lesions in melanoma-prone families. Cancer 2002; 94:3192-209.

8. Landi MT, Baccarelli A, Tarone RE, Pesatori A, Tucker MA, Hedayati M, et al. DNA repair, dysplastic nevi, and sunlight sensitivity in the development of cutaneous malignant melanoma. J Natl Cancer Inst; 94:94-101.

9. Hallberg O. A reduced repair efficiency can explain increasing melanoma rates. Eur J Cancer Prev 2008; 17:147-52.

10. Houghton AN, Coit DG, Daud A, Dilawari RA, Dimaio D, Gollob JA, et al. Melanoma. J Natl Compr Canc Netw 2006; 4:666-84.

11. Nova-Villanueva J, Sánchez-Vanegas G, Quintana LP. Cáncer de piel: perfil epidemiológico de un centro de referencia en Colombia 2003-2005. Rev Salud Pública (Bogotá) 2007; 9:595-601. 
12. Pinheiro AMC, Cabral ALSV, Friedman H, Rodrigues HA. Cutaneous melanoma: clinical, epidemiological and histopathological characteristics at the University Hospital of Brasília between January 1994 and April 1999. An Bras Dermatol 2003; 78:179-86.

13. Sortino-Rachou AM, Curado MP, Latorre MRDO. Cutaneous melanoma: population-based study in Goiania, Brazil, from 1988 to 2000. An Bras Dermatol 2006; 81:449-55.

14. Fritz A, Percy C, Jack A, Shanmugaratnam K, Sobin L, Parkin DM, et al. International Classification of Diseases for Oncology (ICD-O). $3^{\text {rd }}$ Ed. Geneva: World Health Organization; 2000.

15. Jensen OM, Parkin DM, MacLennan R, Muir CS, Skeet R. Cancer registration: principles and methods. Lyon: International Agency for Research on Cancer; 1991. (IARC Scientific Publications, 95).

16. Silva IS. Cancer epidemiology: principles and methods. Lyon: IARC Press; 1999.

17. Mack TM, Floderus B. Malignant melanoma risk by nativity, place of residence at diagnosis, and age at migration. Cancer Causes Control 1991; 2:401-11.

18. Horner MJ, Ries LAG, Krapcho M, Neyman N, Aminou R, Howlander N, et al. SEER cancer statistics review, 1975-2006. Bethesda: National Cancer Institute; 2009. http://seer.cancer.gov/ csr/1975_2006/index.html (accessed on 23/ Apr/2009).

19. Desmond RA, Soong S. Epidemiology of malignant melanoma. Surg Clin North Am 2003; 83:1-29.

20. Hanahan D, Weinberg RA. The hallmarks of cancer. Cell 2000; 100:57-70.

21. Peto J. Cancer epidemiology in the last century and the next decade. Nature 2001; 42:705-22.

22. Shoo BA, Kashani-Sabet M. Melanoma arising in African-, Asian-, Latino- and Native-American populations. Semin Cutan Med Surg 2009; 28:96102.

23. Essner R, Kaushal A, Flaherty K. Melanoma and other skin cancers. Cancer management handbook; 2008. http://www.cancernetwork.com/can cer-management-11/chapter23/article/10165/ 1405855 (accessed on 15/Jan/2009).

24. Houghton AN, Polsky D. Focus on melanoma. Cancer Cell 2002; 2:275-8.

25. Souza SRP, Fischer FM, Souza JMP. Suntanning and risk of cutaneous melanoma: a literature review. Rev Saúde Pública 2004; 38:588-98.

26. Coelho SG, Hearing VJ. UVA tanning is involved in the increased incidence of skin cancers in fairskinned young women. Pigment Cell Melanoma Res 2010; 23:57-63.

27. Bakos RM, Wagner MB, Bakos L, DeRose EH, Grangeiro Neto JA. Sunburns and sun habits in a group of Brazilian athletes. Rev Bras Med Esporte 2006; 12:275-8.

28. Pruthi DK, Guilfoyle R, Nugent Z, Wiseman MC, Demers AA. Incidence and anatomic presentation of cutaneous malignant melanoma in central Canada during a 50-year period: 1956 to 2005. J Am Acad Dermatol 2009; 61:44-50.

29. Geller AC, Johnson TM, Miller DR, Brooks KR, Layton CJ, Swetter SM. Factors associated with physician discovery of early melanoma in middle-aged and older men. Arch Dermatol 2009; 145:409-14.
30. Swetter SM, Johnson TM, Miller DR, Layton CJ, Brooks KR, Geller AC. Melanoma in middle-aged and older men. Arch Dermatol 2009; 145:397-404.

31. Hegde UP, Chakraborty N, Kerr P, Grant-Kels JM. Melanoma in the elderly patient: relevance of the aging immune system. Clin Dermatol 2009; 27:537-44.

32. Coory M, Baade P, Aitken J, Smithers M, McLeod GRC, Ring I. Trends for in situ and invasive melanoma in Queensland, Australia, 1982-2002. Cancer Causes Control 2006; 17:21-7.

33. Linos E, Swetter SM, Cockburn MG, Colditz GA, Clarke CA. Increasing burden of melanoma in the United States. J Invest Dermatol 2009; 129:1666-74.

34. MacKie RM, Bray C, Vestey J, Doherty V, Evans A, Thomson D, et al. Melanoma incidence and mortality in Scotland 1979-2003. Br J Cancer 2007; 96:1772-7.

35. Crocetti E, Carli P, Miccinesi G. Melanoma incidence in central Italy will go on increasing also in the near future: a registry-based, age-period-cohort analysis. Eur J Cancer Prev 2007; 16:50-4.

36. Cockburn MG, Zadnick J, Deapen D. Developing epidemic of melanoma in the Hispanic population of California. Cancer 2005; 106:1162-8.

37. Sng J, Koh D, Siong WC, Choo TB. Skin cancer trends among Asians living in Singapore from 1968 to 2006. J Am Acad Dermatol 2009; 61:426-32.

38. Rouhani P, Arheart KL, Kirsner RS. Differences in melanoma outcomes among Hispanic Medicare enrollees. J Am Acad Dermatol 2010; 62:768-76.

39. Hegde UP, Chakraborty N, Kerr P, Grant-Kels JM. Melanoma in the elderly patient: relevance of the aging immune system. Clin Dermatol 2009; 27:537-44.

40. Seidler AM, Pennie ML, Veledar E, Culler SD, Chen SC. Economic burden of melanoma in the elderly population: population-based analysis of the Surveillance, Epidemiology, and End Results (SEER): Medicare data. Arch Dermatol 2010; 146:249-56.

41. Aceituno-Madera P, Buendia-Eisman A, AriasSantiago S, Serrano-Ortega S. Evolución de la incidencia del cáncer de piel en el período 1978-2002. Actas Dermosifiliogr 2010; 101:39-46.

42. Bakos L, Masiero NC, Bakos RM, Burttet RM, Wagner MB, Benzano D. European ancestry and cutaneous melanoma in Southern Brazil. J Eur Acad Dermatol Venereol 2009; 23:304-7.

43. Rigel DS. Cutaneous ultraviolet exposure and its relationship to the development of skin cancer. J Am Acad Dermatol 2008; 58:S129-32.

44. Heard AR, Coventry BJ, Milanowski B, Taylor D. The geography of melanoma in South Australia. Aust N Z J Public Health 2009; 33:105-8.

45. Godar DE, Landry RJ, Lucas AD. Increased UVA exposures and decreased cutaneous Vitamin D3 levels may be responsible for the increasing incidence of melanoma. Med Hypotheses 2009; 72:434-43.

46. Hallberg O, Johansson O. Malignant melanoma of the skin: not a sunshine story! Med Sci Monit 2004; 10:CR336-40.

\section{Submitted on 02/Apr/2010}

Final version resubmitted on 20/Sep/2010

Approved on 29/Nov/2010 